\title{
ARCHIBALD EDWARD GARROD - ŻYCIE I DROGA ZAWODOWA OJCA GENETYKI BIOCHEMICZNEJ. CZĘŚĆ I. ALKAPTONURIA
}

\author{
ARCHIBALD EDWARD GARROD - LIFE AND CAREER PATH OF THE FATHER OF BIOCHEMICAL \\ GENETICS. PART I. ALCAPTONURIA
}

\section{Dariusz Walkowiak}

Katedra Prawa Medycznego, Organizacji i Zarządzania w Opiece Zdrowotnej, Uniwersytet Medyczny im. Karola Marcinkowskiego w Poznaniu

DOI: https://doi.org/10.20883/ppnoz.2019.70

\begin{abstract}
STRESZCZENIE
Sir Archibald Edward Garrod, syn Sir Alfreda Baringa Garroda, lekarza królewskiego królowej Wiktorii, był postacią, która niewątpliwie odcisnęła piętno na współczesnej medycynie. Chemik, lekarz, autor tezy o autosomalnym recesywnym dziedziczeniu alkaptonurii, twórca pojęcia „wrodzone błędy metabolizmu”. Choć na świecie jest powszechnie uznawany za ojca genetyki biochemicznej, w Polsce jest mało znany. Artykuł niniejszy, będący pierwszym z serii dwóch, stanowi próbę przywrócenia Archibaldowi Garrodowi należnego mu miejsca w polskim czasopiśmiennictwie medycznym. Przedmiotem artykułu będą dokonania naukowe Garroda, pokazane na tle epoki. Zarysowana zostanie również historia rodziny oraz relacje naukowe i towarzyskie z innymi wybitnymi naukowcami tamtych czasów, takimi jak Frederick Gowland Hopkins czy William Bateson.
\end{abstract}

Słowa kluczowe: Archibald Edward Garrod, wrodzone błędy metabolizmu, alkaptonuria, genetyka biochemiczna.

ABSTRACT

Sir Archibald Edward Garrod, son of Sir Alfred Baring Garrod, royal physician of Queen Victoria, was a figure that undoubtedly left a mark on modern medicine. Chemist, medicine doctor, author of the thesis on autosomal recessive inheritance of alkaptonuria, the father of "inborn errors of metabolism". Although he is considered by many to be the founding father of biochemical genetics, nobody in Poland has yet devoted scholarly attention to his work. This article, being the first in a series of two, is an attempt to restore Archibald Garrod to his rightful place in Polish medical literature. The subject of the article will be Garrod's scientific achievements, shown against the backdrop of his era. The history of his family, as well as scientific and social relations with other outstanding scientists of that time, such as Frederick Gowland Hopkins or William Bateson, will also be outlined.

Keywords: Archibald Edward Garrod, inborn errors of metabolism, alkaptonuria, biochemical genetics.

Odkrycia Archibalda Edwarda Garroda z punktu widzenia biochemii medycznej mają charakter wyjątkowy [1]. Jest uznawany za tego, któremu udało się połączyć Mendlowską genetykę z teorią doboru naturalnego Darwina i jednocześnie przełożyć na język praktycznej medycyny [2]. Pochodzący z 1902 r. artykuł [3], stawiający tezę o autosomalnym recesywnym dziedziczeniu alkaptonurii, uznaje się za kamień milowy w rozwoju genetyki człowieka i jej zastosowaniu w medycynie [4]. Motulsky [5], pisząc o odkryciach Garroda, postawił nawet tezę o "koncepcji wyprzedzającej swoje czasy". Motulsky bezpośrednio nawiązywał do teorii Stenta o odkryciach czy koncepcjach wyprzedzających swoje czasy, których nie daje się połączyć $z$ istniejącą $w$ danym momencie wiedzą [6] i nawet jeżeli ta opinia jest trochę na wyrost, to nie da się ukryć, że rola Garroda w rozwoju nauki jest kolosalna. Artykuł niniejszy jest próbą omówienia życia i dorobku wybitnego naukowca, który dotąd nie doczekał się należnego mu miejsca w polskiej literaturze medycznej.
Dziadek Archibalda, Robert Garrod, był synem drobnego dzierżawcy rolnego wStradbroke. Terminowałw browarze w Ipswich należącym do ojca właściciela ziemskiego, u którego pracował jego ojciec, a później założył firmę zajmującą się pośrednictwem w obrocie nieruchomościami [7]. Ojciec Archibalda, Alfred Baring, urodził się w Ipswich w 1819 r., tam też uczęszczał do szkoły. Pomimo handlowego nastawienia ojca, Alfred szybko zdecydował, że zostanie lekarzem. Jak pisze biograf Garroda, Alexander G. Bearn, bycie lekarzem w tamtych czasach w Anglii nie było czymś szczególnie prestiżowym, takim jak bycie oficerem, prawnikiem czy pastorem [7]. Jednak młody Alfred rozpoczął naukę u lekarza, sąsiada rodziców, którą już w formalny sposób kontynuował w University College Hospital na Uniwersytecie Londyńskim. Studia ukończył w 1848 r., a już w 1855 r. opublikował pierwsze ze swoich dzieł z zakresu chorób reumatycznych. The essentials of materia medica, therapeutics and the pharmacopoeia doczekało się 13 wydań, a autor w 1858 r. został wybrany do 
prestiżowego Royal Society. W 1862 r. rozpoczął leczenie w prestiżowym King's College Hospital w Londynie i został profesorem w King's College. W 1874 r. porzucił jednak pracę w szpitalu i skoncentrował się na dochodowej praktyce prywatnej. W 1887 r. Alfred Garrod z rąk królowej Wiktorii otrzymał tytuł szlachecki, a rok później został lekarzem królewskim. Wtedy też udało mu się podnieść, wysoką już wcześniej, stawkę za wizytę prywatną z jednej do dwóch gwinei [8]. Zmarł w 1907 r. jako niezwykle zamożny człowiek. Archibald (nazywany przez rodzinę Archi) Edward Garrod był najmłodszym z synów Sir Alfreda Baringa Garroda. Rodzice Archibalda mieli sześcioro dzieci, czterech chłopców i dwie dziewczynki. Archie był piątym, urodzonym w 1857 r. dzieckiem. Najstarszy z synów, Alfred Henry, był utalentowanym lekarzem, a także zoologiem i ze względu na osiągnięcia w tej drugiej dziedzinie został członkiem Royal Society w wieku 30 lat; niespodziewanie zmarł na gruźlicę trzy lata później. Młodszy, Charles Robert, umarł na gruźlicę $w$ wieku siedemnastu lat, jeszcze przed swoim starszym bratem. Kolejny z synów, Herbert Baring, był adwokatem i utalentowanym poetą, zwycięzcą prestiżowej nagrody Newdigate Prize na Uniwersytecie w Oxfordzie w 1869 r. [9]. Z dwóch córek, młodsza Helen podobnie jak dwaj najstarsi bracia, zmarła na gruźlicę w wieku 32 lat, a druga, Edith Kate, zajmowała się domem swoich rodziców. Po ich śmierci samotnie mieszkała w rodzinnej rezydencji na wsi [7].

Archibald Garrod naukę rozpoczął w wieku jedenastu lat w szkole w Harrow i kontynuował w publicznej szkole Marlborough College w Wiltshire. Nie był wybitnym uczniem, co nie przeszkodziło mu, jak widać, w spektakularnej karierze naukowej. Jednak już wtedy widoczne było ukierunkowanie zainteresowań młodego Archiego na nauki ścisłe. Po ukończeniu szkoły oraz roku specjalnych kursów chemicznych na University College w Londynie Archibald rozpoczął w 1877 r. studia z zakresu chemii na wchodzącym w skład Uniwersytetu Oxfordzkiego Christchurch Oxford. W 1879 r. zdobył przyznawaną co cztery lata Johnson Memorial Prize za prace „z dziedziny astronomii lub meteorologii". Studia medyczne rozpoczął w $1880 \mathrm{r}$. w St Bartholomew's Hospital w Londynie, który nie tylko był najstarszym i jednym z najbardziej szacownych angielskich szpitali (powstał w 1123 r.), ale od 1839 r. kształcił również studentów medycyny jako część Uniwersytetu Londyńskiego [10]. Historycy medycyny uważają, że to w latach 1880-1920 St Bartholomew's Hospital był najbardziej prestiżowym szpitalem brytyjskim [11]. Intelektualne zdolności młodego Archibalda w pełni rozkwitty w trakcie studiów medycznych; był wybitnym studentem. W $1881 \mathrm{r}$. otrzymał Junior Scholarship Prize, a w 1884 r. Brackenbury
Scholarship in Medicine. W 1882 r. przerobił i własnym kosztem wydrukował swoją pracę z zakresu astronomii, za którą wcześniej otrzymał nagrodę. Czterdziestoczterostronicowy esej zadedykował swojemu ojcu i swojej przyszłej żonie Laurze Elizabeth Smith. Jak napisał Bearn, można mieć wątpliwości, czy osiemnastoletnia Laura była pracą z zakresu astronomii równie podekscytowana, jak jego ojciec. Wakacje 1884 r. spędził w Norwegii, gdzie dotarł do wioski w okolicach Bergen zamieszkałej przez chorych na trąd. W wyniku tej wizyty Garrod napisał swoją pierwszą pracę z zakresu medycyny [12]. Zawarł w niej kliniczny opis choroby wraz z jej historią, ale też opisał zachodnią Norwegię [7]. Również w 1884 r. Garrod został członkiem Royal College of Surgeons. W styczniu i lutym 1885 roku Garrod przebywał na stażu w Allgemeines Krankenhouse w Wiedniu. Wizyta zaowocowała nie tylko obserwacjami dotyczącymi innej organizacji pracy lekarzy na kontynencie, ale również kolejną pozycją $w$ dorobku naukowym. Uczestnicząc w zajęciach z laryngologii, zapoznał się szerzej z mniej popularnym na Wyspach laryngoskopem, co opisat w pracy An introduction to the use of the laryngoscope. W tym samym roku otrzymał tytuły bakałarza w zakresie medycyny oraz w zakresie chirurgii na Uniwersytecie w Oxfordzie. Z punktu widzenia praktyki lekarskiej nie było to niezbędne, ale Garrod już wtedy myślał o karierze akademickiej [7]. Pracę rozpoczął pod kierunkiem Sir Dyce'a Duckwortha, przyjaciela ojca i późniejszego osobistego lekarza księcia Walii oraz członka pierwszego zarządu Royal British Nursing Association [13, 14]. To Duckworth naciskał, by młody lekarz przyjmował jak największą liczbę pacjentów z różnorodnymi schorzeniami. I to również Duckworth zachęcał do publikowania case studies dotyczących szczególnych przypadków zaobserwowanych $w$ trakcie wizyt i leczenia [15]. Również w 1885 r. Garrod zdał egzamin uprawniający do zostania członkiem Royal College of Physicians. W kolejnym roku za pracę o reumatoidalnym zapaleniu stawów otrzymał stopień doktora medycyny na Oxfordzie. Był to ważny rok w jego życiu, ponieważ w maju ożenił się z Laurą Elisabeth Smith, córką Sir Thomasa Smitha, chirurga w St Bartholomew's Hospital oraz przyjaciela ojca Archibalda. W prawie dwumiesięczną podróż poślubną młoda para udała się na kontynent, rozpoczynając od Norwegii, później odwiedzając Szwecję, Danię i Niemcy. W trakcie podróży dotarła do nich wiadomość o przyznaniu przez królową Wiktorię ojcu Archibalda szlachectwa. W 1886 r. Garrod został członkiem Royal Medical and Chirurgical Society. W grudniu 1887 r. na świat przyszło pierwsze dziecko młodych małżonków: syn Alfred Noël. Na świat przychodziły kolejne dzieci: Dorothy w 1892 r. Thomas Martin w 1894 r. i Basil 
Rahere w 1897 r. Archibald kontynuował pracę w St Bartholomew's Hospital, ale w 1888 r., korzystając z rady Duckwortha, by pogłębiać swoje doświadczenie jako klinicysta, rozpoczął pracę w West London Hospital. Pozostał tam osiem lat. W tym samym roku, już po trzech latach członkostwa w Royal College of Physicians, został przez swoich kolegów wybrany do wąskiego grona towarzystwa - fellows. Również w 1888 r. ukazała się w czasopiśmie Lancet praca Garroda i E. Hunta Cooke'a będąca pierwszym sygnałem przyszłych zainteresowań Garroda kwestiami dziedziczności chorób [16]. W 1889 r. rozpoczął pracę w Marylebone Clinic. Za pierwszą z poważnych prac Garroda uznaje się $A$ treatise on rheumatism and rheumatoid arthritis napisaną w 1890 r. [7]. Egzemplarz również tej pracy z dedykacją ofiarował ojcu. W 1894 r. wraz z kolegami z St Bartholomew's Hospital Garrod napisał krótki podręcznik z zakresu anatomii patologicznej. W 1892 r. Garrod z ogromną satysfakcją, jak twierdzi Bearn, rozpoczął pracę w Hospital for Sick Children in Great Ormond Street [7], najstarszym angielskim szpitalu zajmującym się leczeniem dzieci, powstałym w 1852 r. Zdania w tej kwestii są podzielone, gdyż jak napisał Galton, Garrod rozpoczął pracę w Hospital for Sick Children in Great Ormond Street ze względów finansowych [17]. W szpitalu tym, jak pisze Lomax [18], widać było skłonność pracujących w nim lekarzy, by przedkładać interesujące przypadki leczone bezpłatnie nad płatnych bogatych, lecz nie zawsze poważnie chorych pacjentów. Sytuacja taka, bez względu na to, jakie były przyczyny rozpoczęcia pracy, wpisywała się zapewne znakomicie w szukającego klinicznych wyzwań Garroda, kontynuującego prace nad chorobami rzadkimi, w tym czasie alkaptonurią oraz porfirynurią. Zapewne ze względu na swoje chemiczne wykształcenie oraz kliniczne doświadczenia zajmował się w tym okresie pigmentami występującymi w moczu pacjentów. Z działalności, która nie była bezpośrednio działalnością medyczną, warto wspomnieć, że w 1896 r. przetłumaczył z niemieckiego pracę swojego znajomego profesora Naunyn'a na temat kamicy żółciowej. Podróże do krajów europejskich oraz przyjmowanie gości z tych krajów u siebie stały się stałym elementem pracy Garroda w tamtym okresie. Wraz z jego rosnącą sławą liczba uczonych chcących go odwiedzić w St Bartholomew's Hospital rosła. Zdarzało się też mu tłumaczyć prace naukowe z niemieckiego lub francuskiego. Również w 1886 r. Sir Clifford Allbutt, profesor medycyny z Uniwersytu w Cambridge, pracując nad ośmiotomowym podręcznikiem A system of medicine, zaprosił Garroda do napisania rozdziału o reumatoidalnym zapaleniu stawów. Mniej więcej w tym samym czasie Garrod poznał pracującego w położonym w pobliżu Guy's Hospital młodego chemika i lekarza Fredericka Gowlanda Hopkinsa. To była przyjaźń do końca życia [19]. W sensie dosłownym, bo to Hopkins po śmierci Garroda napisał wspomnienie pośmiertne dla Royal Society. Laureat Nagrody Nobla w dziedzinie medycyny z $1929 \mathrm{r}$. miał niestandardową drogę naukową. Był absolwentem chemii na studiach wieczorowych w City of London School, studiował na Royal School of Mines, a później ponownie chemię na University College London, gdzie pracował w Institute of Chemistry [20]. W wyniku nieprzeciętnych wyników egzaminów Hopkins trafił do pracy w laboratorium Guy's Hospital, zaproszony przez jego szefa. W trakcie pracy w szpitalu Hopkins zdecydował się podjąć studia medyczne. Znajomość Garroda i Hopkinsa miała kolosalne znaczenie dla dalszej kariery obu naukowców. Hopkins starając się zmierzyć z problemami chemicznymi, fizjologicznymi i patologicznymi szybko zyskał reputację kompetentnego chemika, dzięki przeprowadzanym wysoko wykwalifikowanym analizom chemicznym substancji biologicznych. Badania chemiczne moczu, nad którymi pracował w tym czasie, były zainspirowane przez Garroda. Obaj naukowcy napisali wspólnie na temat obecności urobiliny i hematoporfiryny w moczu dwanaście artykułów. I jakkolwiek wkład Hopkinsa w te prace był niewątpliwie duży, to głównym autorem wszystkich z nich był Garrod i to prawdopodobnie on przeprowadził kluczową dla tych prac analizę spektroskopową. Chociaż należy wspomnieć, że w podręczniku Schäfera Text-book of Physiology to Hopkins napisał rozdział dotyczący chemicznej analizy moczu [21]. Po przeprowadzce do Cambridge Garrod i Hopkins nie współpracowali już naukowo, ale nadal spotykali się na gruncie prywatnym, choć ze względu na dzielącą ich odległość nie tak często jak wcześniej [7].

Gdy Garrod w latach dziewięćdziesiątych XIX w. rozpoczynał pozornie banalny projekt badania występowania niezwykłych pigmentów w moczu, temat bardzo wyśmiewany przez jego kolegów jako „zabawy z moczem”, znajdował się poza głównym nurtem badawczym ówczesnej medycyny, koncentrującej się na zrozumieniu istoty i przeciwdziałaniu chorobom zakaźnym [22]. Ale to umiejętność patrzenia na nierozwiązane kwestie w nowatorski sposób oraz prawidłowego formułowania problemów, przy wykorzystaniu wiedzy z różnych dziedzin, spowodowała, że Garrod, pracując nad z pozoru nieistotnym zagadnieniem, stał się autorem przełomowego odkrycia.

W 1899 r. Garrod opublikował pierwszy ze swoich artykułów dotyczących alkaptonurii. Dziś wiemy, że alkaptonuria jest dziedzicznym zaburzeniem metabolizmu aminokwasów aromatycznych, w wyniku braku aktywności enzymu szlaku katabolicznego fenyloalaniny i tyrozyny - 1,2-dioksygenazy homogentyzynianowej (HGD). 
Kwas homogentyzynowy (HGA) nie jest metabolizowany, gromadzi się w organizmie i jest wydalany z moczem, powodując jego ciemne zabarwienie. Polimer - barwnik ochronotyczny - odkłada się w chrząstkach i tkankach bogatych w kolagen. W dzieciństwie alkaptonuria nie daje żadnych objawów klinicznych. Rozpoznanie choroby może nastąpić już u noworodków, których mocz ciemnieje pod wpływem powietrza, zostawiając ciemne plamy na pieluchach. Co więcej, kontakt z mydłem o zasadowym odczynie intensyfikuje kolor plam i utrudnia ich pranie [23, 24]. I to właśnie kolor moczu przy kontakcie z powietrzem był źródłem nazwy "choroba czarnego moczu". Wiemy, że ze względu na łatwość zaobserwowania, choroba była opisywana już w wiekach średnich. Jak napisał sam Garrod: „Do początku dziewiętnastego wieku nie rozróżniano w literaturze medycznej między uryną, która była czarna już w chwili jej oddawania, a taką, która ciemniała pod wpływem powietrza. Jednak w paru przypadkach opisanych $w$ dziełach z szesnastego i siedemnastego wieku, jak przypadek opisanego przez G.A. Scriboniusa (1584 r.) chłopca, który mimo iż cieszył się dobrym zdrowiem, ciągle wydalał czarny mocz, oraz wspomnianego przez Schencka (1609 r.) mnicha, który przejawiał podobną osobliwość i twierdził, że robił to całe życie, trudno jest postawić inną diagnozę niż alkaptonuria. Najciekawszy tego rodzaju przypadek można znaleźć w pracy Zacutusa Lusitanusa, opublikowanej w 1649 r. Pacjentem był chłopiec, który wydalał czarny mocz i którego w wieku czternastu lat poddano drastycznemu leczeniu mającemu na celu ujarzmienie ognistego żaru jego trzewi, powodującego, jak mniemano, zwęglanie i czernienie jego żółci, co dawało objaw, o którym mowa. Wśród przepisanych środków było upuszczanie krwi, zabiegi przeczyszczające, kąpiele, zimna i wodnista dieta oraz liczne leki. Żadne z powyższych nie przyniosło widocznego efektu, a ostatecznie pacjent, zmęczony daremną i zbyteczną terapią, postanowił pozwolić rzeczom na naturalny bieg. Żaden z przewidzianych strasznych skutków nie nastąpił: pacjent ożenił się, spłodził liczne potomstwo i żył długo i szczęśliwie, nadal oddając mocz czarny jak atrament" [25]. Jednak najstarszy potwierdzony przypadek alkaptonurii rozpoznano u egipskiej mumii o imieniu Harwa, datowanej na 1500 r. p.n.e., znajdującej się dzisiaj w Field Museum w Chicago [26, 27]

Garrod w swoich artykułach dotyczących alkaptonurii nawiązywał do współczesnych mu ustaleń poczynionych przez innych badaczy zajmujących się tą chorobą. W drugiej połowie XIX w. ukazało się kilka prac o alkaptonurii, z których za najważniejsze uznać należy opisy pacjenta poczynione przez Bödekera $[28,29]$ oraz próby wyodrębnienia z moczu pacjentów związku chemicznego odpowiedzialnego za jego kolor, prowadzone przez Marshalla [30], Kirka [31, 32] i w końcu Wolkowa i Baumanna [33]. W swoim pierwszym artykule na temat alkaptonurii, przedstawionym również na spotkaniu Royal Medical \& Chirurgical Society Garrod zebrał i przeanalizował wszystkie dotąd znane i opisane przez innych badaczy przypadki dwudziestu czterech osób chorych na alkaptonurię, dodając siedem nowych przypadków. W opisanej grupie chorych było dwudziestu trzech mężczyzn i chłopców oraz osiem kobiet i dziewczynek. Garrod nie postawił w jasny sposób tezy o częstszym występowaniu alkaptonurii u chłopców, ale ta dysproporcja przykuła jego uwagę W sposób oczywisty zwrócił też uwagę na pokrewieństwo pomiędzy pacjentami, ponieważ większość z nich miała chorego brata lub siostrę. Chorzy mieli jednak zwykle oprócz chorego również zdrowe rodzeństwo. Garrod uznał za interesujący fakt, że w przypadku alkaptonurii wystepującej u rodzeństwa, jeżeli urodziło się chore dziecko, nie oznaczało to, że kolejne będzie również chore. $\mathrm{Na}$ przykład, wśród czternaściorga rodzeństwa tylko dzieci urodzone jako dziewiąte, jedenaste, trzynaste i czternaste były chore. Garrod zwrócił uwagę, że dziesiąte i dwunaste spośród tego rodzeństwa były zdrowe. Nie udało się też ustalić ani jednego przypadku dziedziczenia alkaptonurii, ale również $w$ żaden sposób znaleźć potwierdzenia tezy Wolkowa i Baumanna, że alkaptonuria może być zakaźna [34]. Co interesujące, wydaje się, że objawy pojawiające się u chorych, poza kolorem moczu, nie wzbudzały szczególnego zainteresowania badacza. Pojawiają się opisy dotyczące chorych po sześćdziesiątym roku życia, cieszących się dobrym zdrowiem. Również w 1899 r. Garrod napisał jeszcze jedną krótką, dwuipółstronicową pracę, na temat ekstrakcji HGA z moczu chorych na alkaptonurię, będącą modyfikacją ekstrakcji przedstawionych przez Kirka oraz Wolkowa i Baumanna [35].

W 1901 r., najpierw na posiedzeniu towarzystwa naukowego, a później w formie artykułu Garrod przedstawił rozwinięcie wcześniejszych ustaleń [36]. Wtedy Garrod po raz pierwszy zasugerował, że przyczyną alkaptonurii jest coś, co na początku nazwał odchyleniem od normy, o charakterze chemicznym, występujące $w$ organizmie chorego, "anomalię chemiczną, mniej więcej analogiczną do strukturalnej deformacji”. Napisał też, że „istnieją dobre powody, by sądzić, że alkaptonuria nie jest przejawem choroby, ale raczej jest rodzajem alternatywnego przebiegu metabolizmu, nieszkodliwego i zwykle wrodzonego, a trwającego całe życie". Pytanie, które nurtowało Garroda, brzmiało: czy zwiększone wydalanie HGA po spożyciu posiłku zawierającego białko następuje ze względu na działanie bakterii $w$ jelitach przekształcających tyrozynę 
w HGA, jak sądzono, czy jak przypuszczał Garrod, ze względu na metabolizm HGA występujący głównie w tkankach? Innymi słowy, czy istnieje blok metaboliczny prawdopodobnie spowodowany, jak zasugerował Garrod, brakiem enzymu w tkankach osób chorych na alkaptonurię, który uniemożliwia dalszy metabolizm HGA? Drugą kluczową kwestią było ustalenie, że w znacznej części przypadków rodzice osób chorych na alkaptonurię byli ze sobą blisko spokrewnieni.

W grudniu 1902 r. ukazała się najważniejsza z dotychczasowych prac Garroda. Opisywana grupa chorych wzrosła do czterdziestu. W dziewiętnastu przypadkach chorych pochodzących z jedenastu rodzin udało się ustalić pokrewieństwo pomiędzy rodzicami. Okazało się, że w sześciu rodzinach z chorymi dziećmi rodzice byli kuzynami pierwszego stopnia, a w jednej ojciec chorego dziecka był chory na alkaptonurię [37]. Bearn przygotowując biografię Garroda prześledził jego niepublikowaną wcześniej korespondencję z Williamem Batesonem, botanikiem, propagatorem praw dziedziczenia Gregora Mendla, twórcą terminu genetyka [7, 38]. I w tych okolicznościach, ponieważ praca niniejsza jest poświęcona „ojcu genetyki biochemicznej", kontakty z twórcą terminu "genetyka" nadają ich naukowym związkom dodatkowy kontekst. Panowie korespondowali ze sobą od końca 1901 r., niestety Bearn miał dostęp wyłącznie do listów pisanych przez Garroda, nie można więc wyciągać żadnych kategorycznych wniosków, ale faktem jest, że dyskutowanym tematem była alkaptonuria. Bearn nazywa co prawda Batesona uczniem Garroda, ale lektura wcześniejszych prac Batesona $[39,40,41]$ daje podstawy do twierdzenia, że ich intelektualna relacja była zapewne bardziej równoważna. Wydaje się, że obu uczonym korespondencja ta przyniosła intelektualną korzyść, która widoczna jest w ich pracach $[7,38]$. W swoim raporcie z 1902 r. (Bearn pisze, że z 1901 r. [42]) przygotowanym dla Evolution Committee of the Royal Society Bateson wraz z Saunders relacjonowali ustalenia Garroda w kwestii pokrewieństwa rodziców chorych na alkaptonurię. Napisali również: „Możliwe są oczywiście inne wyjaśnienia, ale zauważamy, że kojarzenie pierwszych kuzynów stwarza warunki, które najprawdopodobniej pozwolą na ujawnianie się cech rzadkich i zwykle recesywnych. Jeśli nosiciel takiej cechy kojarzony jest z osobą niebędącą jej nosicielem, trudno będzie tę cechę kiedykolwiek zaobserwować; ale kuzyni pierwszego stopnia będą często nosicielami zbliżonych komórek rozrodczych, które mogą się spotkać i doprowadzić do ujawnienia się cech recesywnych w powstałej zygocie" [39]. Spostrzeżenie, że osoby chore mają blisko spokrewnionych rodziców, znacznie częściej niż wynikałoby to z odsetka takich małżeństw w społeczeństwie, stanowiło wsparcie tezy o "pewnej osobliwości rodziców, która mogła zostać ukryta przez pokolenia" i o możliwości ujawnienia się tej cechy w przypadku dwojga spokrewnionych rodziców, nosicieli tej cechy. To pokrewieństwo między rodzicami osób chorych na alkaptonurię pozwoliło na postawienie tezy o dziedziczeniu choroby zgodnie z regułami opisanymi przez Mendla, dało też podstawy do twierdzenia o autosomalnym recesywnym dziedziczeniu choroby.

Garrod kontynuował swoje badania w kolejnych latach, a jego najważniejsza praca dopiero miała się ukazać. Przedstawione to zostanie w drugiej części niniejszego artykułu.

\section{Oświadczenia}

Oświadczenie dotyczące konfliktu interesów

Autorzy deklarują brak konfliktu interesów.

Źródła finansowania

Autorzy deklarują brak źródeł finansowania.

\section{Piśmiennictwo}

1. Piro A, Tagarelli G, Lagonia P, Quattrone A, Tagarelli A. Archibald Edward Garrod and alcaptonuria: "Inborn errors of metabolism" revisited. Genet Med. 2010; 12: 475-6.

2. Bland JS. The Disease Delusion: Conquering the Causes of Chronic Illness for a Healthier, Longer, and Happier Life. Harperwave, New York, 2015.

3. Garrod AE. The incidence of alcaptonuria: a study in chemical individuality. Lancet. 1902; 160: 1616-1620.

4. Speicher M, Antonarakis SE, Motulsky AG. Vogel and Motulsky's human genetics - problems and approaches. 4. Springer, 2010.

5. Motulsky AG. The work of Joseph Adams and Archibald Garrod: possible examples of prematurity in human genetics. In: Hook EB (ed) Prematurity and scientific discovery. University of California Press, Berkeley, 2002.

6. Stent GS. Prematurity and Uniqueness in Scientific Discovery. Scientific American. 1972; 227: 84-93.

7. Bearn AG. Archibald Garrod and the Individuality of Man Oxford University Press, New York 1993.

8. Galton DJ. Archibald E. Garrod (1857-1936) J Inherit Metab Dis. 2008; 31: 561-566.

9. Reilly CW. Mid-Victorian Poetry 1860-1879 An Annotated Biobibliography. Mansell Publishing Limited, London and New York, 2000.

10. Waddington K. Medical Education at St. Bartholomew's Hospital, 1123-1995. Boydell Press, Woodbridge 2003.

11. Wall R. "Natural", "Normal": Discourse and Practice at St. Bartholomew's Hospital, London, and Addenbrooke's Hospital, Cambridge, 1880-1920. Forum Qualitative Sozialforschung / Forum: Qualitative Social Research, 2007;8(1), Art. 17, http://nbn-resolving.de/urn:nbn:de:0114-fqs0701174 (dostęp 23.09.18)

12. Garrod AE. A visit to the leper hospital at Bergen. St Bart's Hosp Rep. 1884; 30: 311-313.

13. Nolan P. A History of Mental Health Nursing. Nelson Thornes Ltd. Cheltenham, 1992.

14. Obituary. Sir Dyce Duckworth. BMJ 1928; 28: 161-162.

15. Garrod AE. Some cases of sclerosisof the spinal cord. St Bart's Hosp. Rep. 1885; 21: 93-99. 
16. Garrod AE. Cooke Hunt E. An attempt to determine the frequency of rheumatic family histories amongst non-rhuematic patients. Lancet. 1888; 132: 110

17. Galton DJ. Standing on the Shoulders of Darwin and Mendel: Early Views of Inheritance. CRC Press, Taylor \& Francis, Boca Raton, London, New York 2018.

18. Lomax EM. Small and special: the development of hospitals for children in Victorian Britain. Med Hist Suppl. 1996; 161-217.

19. Caldwell J. Drug metabolism and pharmacogenetics: the British contribution to fields of international significance. Br J Pharmacol. 2006; 147 (Suppl 1): S89-S99.

20. Stephenson M. Obituary Notice: Frederick Gowland Hopkins, 1861-1947. Biochem J. 1948; 42: 161-169.

21. Kamminga $\mathrm{H}$, Weatherall MW. The making of a biochemist I: Frederick Gowland Hopkins' construction of dynamic biochemistry. Med Hist. 1996; 40: 269-292.

22. Galton DJ. Archibald E Garrod: The Founding Father of Biochemical Genetics. In: Thompson B. (ed.) Pioneers of Medicine Without a Nobel Prize. Imperial College Press, London, 2014.

23. Cabalska B, (ed.) Wybrane choroby metaboliczne u dzieci. Warszawa: PZWL; 2002.

24. Rovenský J, Urbánek T, Stančíková M. The clinical picture of alkaptonuria and ochronosis. Obraz kliniczny alkaptonurii i ochronozy. Reumatologia. 2012; 4: 324-335.

25. Garrod AE. Croonian Lecture II, Alkaptonuria. Lancet. 1908 2: $73-79$.

26. Stenn FF, Milgram JW, Lee SL, Weigand RJ, Veis A. Biochemical identification of homogentisic acid pigment in an ochronotic egyptian mummy. Science. 1977; 197: 566-8.

27. (ed.) David AR. Manchester Museum Mummy Project: Multidisciplinary Research on Ancient Egyptian Mummified Remains. Manchester University Press. Manchester, 1986.

28. Bödeker C. Ueber das Alcapton. Ztschr f rat Med. 1859: 130.

29. Boedeker C. Das Alkapton; ein Beitrag zur Frage: welche Stoffe des Harns können aus einer alkalinischen Kupferoxydlösung Kupferoxydul reduciren? Ann Chem Pharmacol. 1861; 117: 98.

30. Marshall J. A Preliminary Notice of a Crystalline Acid in Urine Possessing More Powerful Reducing Properties than Glucose. Med. News (Philadelphia). 1887; 50: 35-37.
31. Kirk R. On a New Acid Found in Human Urine which Darkens with Alkalies. Brit. AM. J. 1886; II: 1017-1019.

32. Kirk R. On a New Acid Found in Human Urine which Darkens with Alkalies. J. Anat. \& Physiol. 1889; 23: 69-80.

33. Wolkow M, Baumann E. Uber das Wesen der Alkaptonurie. Zschr. physiol. Chem. 1891; 15: 228-285.

34. Garrod AE. A contribution to the study of alkaptonuria. Med Chir Trans. 1899; 82: 367-394.

35. Garrod AE. Alkaptonuria: a simple method for the extraction of Homogentisinic Acid from the Urine. Journal of Physiology. 1899; 23: 512-514.

36. Garrod AE. About alkaptonuria. Lancet. 1901; 2: 1484-1486.

37. Garrod AE. The incidence of alkaptonuria: a study in chemical individuality. Lancet. 1902; 160: 1616-1620.

38. Bateson P. William Bateson: a biologist ahead of his time. J Genet. 2002; 81: 49-58.

39. Bateson W, Saunders ER. The facts of heredity in the light of Mendel's discovery. Reports to the Evolution Committee of the Royal Society, I. 1902.

40. Bateson W. Hybridisation and cross-breeding as a method of scientific investigation. Journal of the Royal Horticultural Society. 1899; 24: 59-66.

41. Bateson W. Problems of Heredity as a Subject for Horticultural Investigation. Journal of the Royal Horticultural Society. 1900; 25: 54-61.

42. Bearn AG. Archibald Edward Garrod, the Reluctant Geneticist. Genetics. 1994; 37: 1-4.

Zaakceptowano do edycji: 15.12.2019 Zaakceptowano do publikacji: 15.02.2020

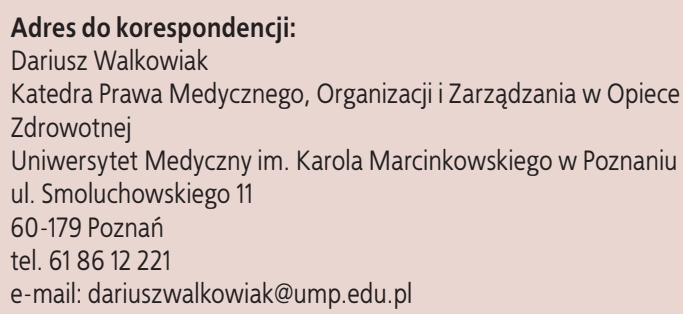

